\title{
ASSESSMENT OF WATER AVAILABILITIES IN THE TANCÍTARO AREA THROUgH THE FUZZY WILLINGNESS TO PAY
}

\author{
José M. Brotons ${ }^{1}$, Gerardo Ruiz Sevilla ${ }^{2}$, Ruben Chavez $^{3}$ \\ ${ }^{1}$ Department of Economic and Financial Studies, \\ Miguel Hernández University, Elche, 03202 Alicante, Spain \\ ${ }^{2}$ Escuela Nacional de Estudios Superiores. Universidad Nacional \\ Autónoma de México, Campus Morelia, México \\ ${ }^{3}$ Facultad de Químico Farmacobiología, Universidad Michoacana de San \\ Nicolás de Hidalgo, Morelia, Michoacán. México
}

\begin{abstract}
The Tancítaro peak is located in the State of Michoacán in Mexico. The current situation of unsustainable consumption of water resources can lead the region to a critical situation if adequate measures are not taken. An improvement in water management involving paying for the use of these resources could improve the situation. This work aims to propose a model allowing obtaining an equilibrium price of the use of water in the Tancitaro area. For this, experts will be consulted among the users of the water and experts among those who currently the right to use it, that is, inhabitant of the reserve area. The use of the Fuzzy logic will allow them to express their willingness to pay and collect data, not in a dichotomous way, but by grading their opinions. The use of Ordered Weighted Average (OWA) will allow the aggregation of these opinions bearing in mind different degrees of optimism or pessimism. The results obtained show an equilibrium price of $\$ 0.49 \mathrm{~m}^{-3}$. It should be noted that these are preliminary results and the main objective of the work is the presentation of a methodological proposal.
\end{abstract}

\section{KEYWORDS}

OWA, Water demand function, Water supply function, Willingness to accept, Willingness to pay.

\section{INTRODUCTION}

The management of Ecosystem Water Services, from an economic and environmental perspective, allows creating the context to generate the necessary conditions, based on organizational policy, aimed at achieving sustainable and comprehensive development $[1,2]$. In the west central region of Michoacán, Mexico is located the Tancítaro peak. Due to the economic growth and the development, effective management of the environmental services is required as well as rational use of them. It is predicted that by 2030 several large hydrological regions will be found in a critical condition [3]. In Mexico there is a severe crisis caused by deficient water management, aggravated by both, high rates of deforestation and the loss of the Ecosystem Water Services (representing a country's forests and jungles) $[4,5,6]$ 
The economic valuation of water resources plays an important role in two aspects: demand management and distribution for its different uses. Optimized management of water resources requires decisions based on economic efficiency, social equality and, above all, ecological sustainability. The values of water resources depend on the quality, location, reliability of access, and availability among others [6].

The state of Michoacán stands out for its fruit production, mainly Hass Avocado (Persea americana). Back in the eighties, the total percentage occupied by fruit trees was only $42 \%$, representing 21,241 ha, and by 2009 the percentage increased to 55\% (103,602 ha). The state contributes $10 \%$ to the national agricultural Gross Domestic Product (GDP) and agriculture represents $7 \%$ of the total state's GDP, establishing itself as the main economic activity in some regions and municipalities [7]. Currently, in Michoacán, there is a planted area of 169,939 ha, from which 64,808 hectares are irrigated and 105.13 hectares are rainfed. The total production is 548,150 tons per season [8] and since 2018, the great economic growth has generated a positive impact on the regional economy, increasing the producers' income, as well as direct and indirect employment [9]. According to De la Tejera et al. [10] more than 47 thousand direct and 187 thousand indirect jobs have been created since then. To sum up, this activity generates annually around \$ 30,265,787.40 [11].

These orchards consume about 1,800 1/plant/month, consequently, a hectare of avocado containing 156 trees can consume up to 5.2 times more water than the same area of a natural forest with a density of 677 species per ha. The growth of orchards and their economic benefits forces the change from forest to agricultural land and the intensive use of agrochemicals [12].

The region of Tancítaro peak, with an elevation of 3,800 m., is one of the most important hydrological regions in the state due to the production of avocado whose main destination is exportation. The municipality of Tancítaro is part of this avocado strip [13]. The avocado is the source of the development for approximately 39,783 inhabitants, distributed in 81 towns and communities. This region is one of the most important areas of the country for its production [14]. Here, about 30 million $\mathrm{m}^{3}$ of water are reported annually, thus benefiting the agricultural activities and domestic use of the inhabitants [13]. The overexploitation and devastation of the forests have provoked the reduction of water availability for agricultural uses. It is expected that the water valuation improves the use efficiency of the water $[13,14,15]$.

From an economic logic, the resources' exploitation implies the scarcer the resources, the higher the price would have to be paid for their use. Then, the objective will consist on assessing the economic contribution to irrigation in agricultural systems through the payable provision for the obtained benefits [16,17]. Several methodologies have been used for the valuation of environmental goods, such as the willingness to pay (WTP) or to accept, contingent valuation, travel costs methodology or hedonic prices, among others. In general, these methodologies are based on the user's opinions, in which it is no possible to introduce the subjectivity. Several studies have addressed the willingness to pay for water, such as [18] concerning the Savegre River in Costa Rica, where the cost per opportunity methodology was applied [19] focusing on the Yamuna River, New Delhi. In Mexico, Soto [20] used the contingent valuation method to estimate the benefits of the comprehensive project for the sanitation of Alto Atoyac in Puebla. Sanchez [21], in the Apatlaco River calculated the WTP to improve the water quality of the Apatlaco river basin, or Rodríguez and García [22] studied in the Guayalejo Basin in the south of the state of Tamaulipas.

We are aware of the difficulty that entails making this type of assessment. On many occasions, the responses portray a wish rather than an opinion. In other words, a water buyer tends to indicate a low price when interviewed to avoid to pay a higher real price in the future. For these 
reasons, we believe that the introduction of subjectivity will make it possible to express opinions to a better way. As a result, the use of Fuzzy Logic is proposed for a better treatment of the subjectivity. Furthermore, the paper will introduce a methodological proposal for the quantification equilibrium price of the water employing Fuzzy Logic, particularly, in the aggregation of subjective information. The use of fuzzy logic introduces a better treatment of the expert's opinions allowing to graduate in them. However, so far, it has not allowed the graduation of the respondent optimism or pessimism degree. A very common aggregation method is the ordered weighted averaging (OWA) operator introduced by Yager [23]. The OWA operator and its extensions have been used in a wide range of applications [24-29].

In this work, given the increasingly pressing water shortage in the Tancítaro area, we propose to make an approximation to the price that could be applied if the public administration makes the necessary improvements to ensure availability for farmers, in the future. For this purpose, experts representing the stakeholders have expressed its opinions through linguistic labels in an artificial market created to determine the equilibrium price. The use of fuzzy logic allows a better treatment of the information provided by the experts. Finally, the use of OWAs and the confidence assigned to each expert allows a graduation of the results according to different degrees of optimism or pessimism.

\section{MATERIAL AND METHODS}

Next, we will proceed to the estimation of the water demand and supply curves, whose intersection will allow obtaining the equilibrium point.

\subsection{Water demand function}

In order to estimate the supply curve, a group of $\mathrm{J}$ experts has been selected and asked about their willingness to pay a series of prices for water $P=\left\{P_{1}, P_{2}, \ldots, P_{P}\right\}$ to ensure water availability in the future. The expert set are administrator of hydraulic resources (CONAGUA) and Organismo Operador de Aguas (OOAPAS) municipal of Tancítaro, Michoacán. In the same way, we have tested the willingness to accept for the people who had the availability of the water in the reservation area. Prices have been presented in ascending way, so that $P_{i}<P_{i^{\prime}}, i<i^{\prime}$. If experts agree to pay for the use of the water, they will be asked if they are willing to pay $P_{1} \$ \mathrm{~m}^{-3}$. If they are not, the final price would be $0 \$ \mathrm{~m}^{-3}$, and if they are willing to pay $P_{1}$, they would be asked for his willingness to pay for a price $P_{2}$. If the answer is negative, the maximum price would be $P_{I}$ and if it is positive, they would be asked for the next price and so on. Given the subjectivity in each answer, it is accepted that the respondent does not respond with a dichotomous answer (yes / no), but rather that they do so according to linguistic labels such as totally disagree, strongly disagree, disagree, etc. (Table 1). Each of the elements of the table will be assigned a membership function (from zero to one, according to it).

Table 1. Values assigned to the linguistic labels

\begin{tabular}{|l|c|}
\hline Linguistic label & $\boldsymbol{\mu}_{\mathbf{j}}$ \\
\hline 1 Totally disagree & 0.00 \\
\hline 2: Strongly disagree & 0.20 \\
\hline 3: Disagree & 0.40 \\
\hline 4: Neutral & 0.60 \\
\hline 5: True & 0.80 \\
\hline 6: Very true & 1.00 \\
\hline
\end{tabular}


From this information, it is possible to obtain the water demand function. For this purpose, three different assumptions have been considered

1. Using average means.

2. Assigning different degrees of optimism and pessimism, based on the opinions provided by experts through OWAs.

3. According to the confidence degree generated by each expert.

\subsubsection{Using average means}

All experts are equally important. In this way, the price that expert $\mathrm{j}\left(W T P_{j}\right)$ would be willing to pay for water can be obtained as:

$$
W T P_{j}^{l}=\sum_{i=1}^{P} \Delta P_{i} \cdot \mu_{i j}
$$

Being $\mu_{i j}$ the membership function assigned by expert $\mathrm{j}$ to price $\mathrm{i}$ and $\Delta P_{i}=P_{i}-P_{i-1}$, that is, the increase that occurs in each new price provided to the expert to express his willingness to pay, over the previous one. In this way, a series of prices has been obtained representing the price that each expert would be willing to pay $W T P^{l}=\left\{W T P_{1}^{l}, W T P_{2}^{l}, \ldots, W T P_{p}^{I}\right\}$.

In this way, it is already possible to obtain the water demand function since the price offered by each expert is available. The curve will be obtained:

- The abscissa axis $P=\left\{P_{1}, P_{2}, \ldots, P_{P}\right\}$ will be made up of the prices initially provided to the experts.

- The ordinate axis, the membership function of each $P_{i}, \mu^{l}\left(P_{i}\right)$, is obtained by the quotient between the number of experts $\mathrm{n}_{\mathrm{i}}$ who were not willing to pay a price $W T P_{j}$ equal to or lower than $P_{i}$ and the total number of experts who answered (J).

$$
\mu^{l}\left(P_{i}\right)=\frac{n_{i}}{J}
$$

\subsubsection{Assigning different degrees of optimism and pessimism, based on the opinions provided by experts through OWAs.}

An ordered weighted average (OWA) is defined as a mapping of dimension $\mathrm{n}, F: R^{n} \rightarrow R$ that has an associated weighting vector $\mathrm{W}$ of dimension $\mathrm{n}, W^{T}=\left[w_{1}, w_{2}, \ldots w_{n}\right]$, such that $w_{j} \in[0,1]$ and $\sum_{j=1}^{n} w_{j}=1$, with

$$
f\left(a_{1}, a_{2}, \ldots a_{n}\right)=\sum_{j=l}^{n} w_{j} \cdot b_{j}
$$

Where $b_{j}$ is the jth largest of the $a_{i}$.

The essence of OWA [23] is the rearrangement of the elements or arguments, causing aggregation in the $a_{j}$ not associated with a weighting $w_{j}$ but with the placement order instead. 
The weights of expression (3) has been obtained by ordering the prices obtained from the opinions given by the experts $\left(W T P_{j}\right)$ and assigning 1 to the highest, 2 to the second, etc. The weight assigned to position $\mathrm{j}$ is, $2 j /((J+l) J)$, that is, the quotation between the digit assigned to position the WTP price of expert $\mathrm{J}$ in descending order over the total sum of digits (sum of the numbers $1,2, \ldots, J)$. This value will be weighted by $\alpha$ factor representing the degree of optimism or pessimism. The highest positive $\alpha$ values correspond to a greater optimism degree, and the lower $\alpha$ values (even negatives) represent a higher pessimism degree.

$$
\omega_{j}^{p}=\left[\frac{2 \cdot j}{(J+1) \cdot J}\right]^{\alpha}
$$

To obtain a weights sum equal to 1 , the previous weights will be normalized, dividing them by the total sum of weights.

$$
\omega_{j}=\frac{\omega_{j}^{p}}{\sum_{j=1}^{J} \omega_{j}}
$$

In this way, it is possible to obtain the water demand function since the price offered by each expert is available. The curve will be obtained as:

- The abscissa axis, $P=\left\{P_{1}, P_{2}, \ldots, P_{P}\right\}$ will be formed by the initial prices

- The ordinate axis, the membership function of each $W T P_{i}, \mu^{2}\left(P_{i}\right)$ is obtained as the sum of the weights assigned to each of the experts who provided $W T P_{j}$ lower or equal to $P_{i}$.

$$
\mu^{2}\left(P_{i}\right)=\sum_{j=l}^{J} \omega_{j} / W T P_{j} \leq P_{i}
$$

\subsubsection{According to the confidence degree of each expert.}

In this case, each price is weighted according to the importance assigned to each expert. Each of them was assigned a previous probability $\rho_{j}^{*}$ (from 0 to 1 ) depending on the credibility that they generate. Finally, these probabilities are normalized dividing each of them by the total sum of probabilities.

$$
\rho_{j}=\frac{\rho_{j}^{*}}{\sum_{j=1}^{J} \rho_{j}^{*}}
$$

In this way, it is possible to obtain the water demand function since the price offered by each expert is available. The curve will be obtained:

- The abscissa axis $P=\left\{P_{1}, P_{2}, \ldots, P_{P}\right\}$ will be formed by the initial prices

- The ordinate axis indicates the membership function of each $W T P_{i}, \mu^{3}\left(P_{i}\right)$, the sum of the probabilities assigned to each expert who obtained a $W T P_{j}$ lower or equal to each of the prices indicated on the abscissa axis $P=\left\{P_{1}, P_{2}, \ldots, P_{P}\right\}$. 


$$
\mu^{3}\left(P_{i}\right)=\sum_{j=l}^{J} \rho_{j} / W T P_{j} \leq P_{i}
$$

\subsubsection{Water demand function}

It will be obtained aggregating the membership functions obtained for each of the three previous methods

$$
\mu_{i}^{S}=\alpha \mu^{1}\left(P_{i}\right)+\beta \mu^{2}\left(P_{i}\right)+\gamma \mu^{3}\left(P_{i}\right), \text { with } \alpha, \beta, \gamma \geq 0 \text { and } \alpha+\beta+\gamma=1
$$

Where $\alpha$ is the importance assigned to the supply curve obtained considering all the experts the same importance, $\beta$ considering the optimistic or pessimistic attitude of the demand curve and $\gamma$ the importance assigned to the demand functions based on the probabilities assigned to each expert.

\subsection{Water supply function}

The Pico de Tancítaro is made up of 16 hydrological basins together representing $678.1 \mathrm{~km}^{2}$. They are not large bodies of water, rather, they are low flow runoff between $100-200 \mathrm{~m}^{3} \mathrm{~s}^{-1}$, underground hydrography and permeability is medium. So users take advantage of the water through retention or deep excavation. Thus, the study of water demand in the avocado belt focuses on users of the Upper Basin and users of the Lower Middle Basin. As a result, we have proceeded in a similar way to obtain the supply function. Three alternatives will also be used, that is, considering that all experts have the same importance, using OWAs to assign different degrees of optimism and pessimism, and depending on the degree of confidence generated by each expert.

On this occasion, they ask about the price that they will be willing to receive for the resource they have, so they will begin by asking for the higher prices. In this case, the increase indicated in the expression (1) refers to the price reduction provided to the experts in each phase.

\subsection{Equilibrium price}

The equilibrium point is defined by the intersection of both curves. The equilibrium point will be given by a price $p_{i}$ and a membership function. The former price $p_{0}$ will be the maximum value that a farmer will be willing to pay to obtain water and the minimum that the owner of the resources (inhabitant of the protected areas) will be willing to receive for sharing water resources.

\section{RESUltS}

\subsection{Water demand function}

Table 2 shows the responses of the consulted experts. The first column indicates the expert number, the second the degree of confidence of each expert. The following columns indicate the willingness to pay for each of the offered prices. Thus, expert 1 , who deserves a degree of confidence of 0.7 indicates that he or she is willing to pay 0.5 and $0.30 \$ \mathrm{~m}^{-3}$ of water. However, as the price increases, his willingness to pay decreases. For $0.45 \$ \mathrm{~m}^{-3}$ the expert expresses the opinion with (0.8) and for 0.6 with the expression disagrees $(0.4)$, and for the rest of the prices it indicates that he or she is totally disagreeing (0). A similar methodology has been used in other works such as Brotons \& Sansalvador [30]. The willingness to pay of the first expert is obtained as: 


$$
W T P_{1}=0.15 \cdot 1+0.15 \cdot 1+0.15 \cdot 0.8+0.15 \cdot 0.4+0.15 \cdot 0+0.15 \cdot 0+0.15 \cdot 0=0.48
$$

That is, multiplying the successive increases in each of the prices by the valuation made by the expert for each price. Last column orders the experts by their willingness to pay in descending order.

Table 2. Willingness to pay

\begin{tabular}{|c|c|c|c|c|c|c|c|c|c|c|}
\hline & & \multicolumn{7}{|c|}{ Willingness to pay } & & \\
\hline Expert & Confidence & 0.15 & 0.3 & 0.45 & 0.6 & 0.75 & 0.9 & 1.05 & WTP & Order \\
\hline 1 & 0.70 & 1.0 & 1.0 & 0.8 & 0.4 & 0.0 & 0.0 & 0.0 & 0.48 & 6 \\
\hline 2 & 0.60 & 1.0 & 1.0 & 1.0 & 1.0 & 0.8 & 0.4 & 0.0 & 0.78 & 3 \\
\hline 3 & 0.10 & 1.0 & 1.0 & 1.0 & 1.0 & 0.8 & 0.6 & 0.2 & 0.84 & 2 \\
\hline 4 & 1.00 & 1.0 & 0.6 & 0.2 & 0.0 & 0.0 & 0.0 & 0.0 & 0.27 & 8 \\
\hline 5 & 0.20 & 0.4 & 0.2 & 0.0 & 0.0 & 0.0 & 0.0 & 0.0 & 0.09 & 10 \\
\hline 6 & 0.90 & 1.0 & 1.0 & 1.0 & 0.4 & 0.2 & 0.0 & 0.0 & 0.54 & 5 \\
\hline 7 & 1.00 & 1.0 & 1.0 & 0.8 & 0.2 & 0.0 & 0.0 & 0.0 & 0.45 & 7 \\
\hline 8 & 1.00 & 1.0 & 1.0 & 1.0 & 0.8 & 0.6 & 0.2 & 0.0 & 0.69 & 4 \\
\hline 9 & 0.30 & 1.0 & 1.0 & 1.0 & 1.0 & 1.0 & 1.0 & 0.7 & 1.005 & 1 \\
\hline 10 & 0.70 & 0.8 & 0.0 & 0.0 & 0.0 & 0.0 & 0.0 & 0.0 & 0.12 & 9 \\
\hline
\end{tabular}

Next, the weights of each expert are shown in Table 3 in three different ways. The first one was obtained assigning equal importance to each expert (average), the second using OWAs: the weight of each expert was obtained according to the opinion expressed in the previous table (WTP), where the WTP were obtained according to expressions (4) and (5), and considering $\alpha=0.8$. In this case, experts who expressed higher prices were overweighed and the experts who express lower prices were underweighted. OWAs had also been used to estimate unknown values, for example in Sansalvador \& Brotons [31]. In the final way, the weight of each expert has been assigned according to the allocated probability and has been obtained according to expression (7).

Table 3. Weights for willingness to pay

\begin{tabular}{|c|c|c|c|}
\hline Expert & Average & OWA & Probability \\
\hline 1 & 0.100 & 0.095 & 0.108 \\
\hline 2 & 0.100 & 0.138 & 0.092 \\
\hline 3 & 0.100 & 0.152 & 0.015 \\
\hline 4 & 0.100 & 0.063 & 0.154 \\
\hline 5 & 0.100 & 0.026 & 0.031 \\
\hline 6 & 0.100 & 0.110 & 0.138 \\
\hline 7 & 0.100 & 0.080 & 0.154 \\
\hline 8 & 0.100 & 0.124 & 0.154 \\
\hline 9 & 0.100 & 0.165 & 0.046 \\
\hline 10 & 0.100 & 0.046 & 0.108 \\
\hline
\end{tabular}

Membership functions are shown in Table 4. For each WTP, the sum of the weights assigned to each expert who has express that the price to be paid was equal to or lower to the one shown in the first column Table 4. The added value has been obtained by assigning 0.2 to the "average", 0.4 to the OWA, and 0.4 to the corresponding probability. Las column of Table 4 shows the demand function. Similar weightings have been used in works such as Sansalvador \& Brotons 
[31] where a new method for the economic evaluation of the ISO 9001 certification was developed.

Table 4. Membership functions for willingness to pay

\begin{tabular}{|r|c|c|c|c|c|}
\hline WTP & Answers & $\boldsymbol{\mu}$ average & $\boldsymbol{\mu}$ OWA & $\boldsymbol{\mu}$ probability & $\boldsymbol{\mu}$ weighted average \\
\hline 0.00 & 10 & 1.00 & 1.00 & 1.00 & 1.00 \\
\hline 0.15 & 8 & 0.80 & 0.93 & 0.86 & 0.88 \\
\hline 0.30 & 7 & 0.70 & 0.86 & 0.71 & 0.77 \\
\hline 0.45 & 7 & 0.70 & 0.86 & 0.71 & 0.77 \\
\hline 0.60 & 4 & 0.40 & 0.58 & 0.31 & 0.44 \\
\hline 0.75 & 3 & 0.30 & 0.46 & 0.15 & 0.30 \\
\hline 0.90 & 1 & 0.10 & 0.17 & 0.05 & 0.10 \\
\hline 1.05 & 0 & 0.00 & 0.00 & 0.00 & 0.00 \\
\hline
\end{tabular}

\subsection{Water supply function}

Similarly, Table 5 shows the willingness to accept the prices for sharing their available water resources.

Table 5. Willingness to accept

\begin{tabular}{|c|c|c|c|c|c|c|c|c|c|c|}
\hline & & \multicolumn{7}{|c|}{ Willingness to accept } & & \\
\hline Expert & Confidence & 0.15 & 0.3 & 0.45 & 0.6 & 0.75 & 0.9 & 1.05 & WTP & order \\
\hline 1 & 0.8 & 0.0 & 0.0 & 0.4 & 0.8 & 1.0 & 1.0 & 1.0 & 0.42 & 6 \\
\hline 2 & 0.6 & 0.0 & 0.0 & 0.0 & 0.0 & 0.4 & 0.8 & 1.0 & 0.72 & 2 \\
\hline 3 & 0.0 & 0.0 & 0.0 & 0.0 & 0.0 & 0.4 & 0.6 & 0.8 & 0.78 & 1 \\
\hline 4 & 1.0 & 0.0 & 0.6 & 0.8 & 1.0 & 1.0 & 1.0 & 1.0 & 0.24 & 8 \\
\hline 5 & 0.0 & 0.0 & 0.2 & 0.4 & 0.6 & 0.8 & 1.0 & 1.0 & 0.45 & 4 \\
\hline 6 & 0.2 & 0.0 & 0.0 & 0.0 & 0.2 & 0.4 & 0.8 & 1.0 & 0.69 & 3 \\
\hline 7 & 0.3 & 0.0 & 0.0 & 0.2 & 1.0 & 1.0 & 1.0 & 1.0 & 0.42 & 5 \\
\hline 8 & 0.1 & 1.0 & 1.0 & 1.0 & 0.8 & 0.6 & 0.2 & 0.0 & 0.36 & 7 \\
\hline 9 & 0.3 & 0.7 & 1.0 & 1.0 & 1.0 & 1.0 & 1.0 & 1.0 & 0.05 & 10 \\
\hline 10 & 0.7 & 0.2 & 1.0 & 1.0 & 1.0 & 1.0 & 1.0 & 1.0 & 0.12 & 9 \\
\hline
\end{tabular}

The weights allocated to each expert are shown in Table 6

Table 6. Expert Weights for willingness to accept

\begin{tabular}{|c|c|c|c|}
\hline Expert & Average & OWA & Probability \\
\hline 1 & 0.100 & 0.095 & 0.200 \\
\hline 2 & 0.100 & 0.152 & 0.150 \\
\hline 3 & 0.100 & 0.165 & 0.000 \\
\hline 4 & 0.100 & 0.063 & 0.250 \\
\hline 5 & 0.100 & 0.124 & 0.000 \\
\hline 6 & 0.100 & 0.138 & 0.050 \\
\hline 7 & 0.100 & 0.110 & 0.075 \\
\hline 8 & 0.100 & 0.080 & 0.025 \\
\hline 9 & 0.100 & 0.026 & 0.075 \\
\hline 10 & 0.100 & 0.046 & 0.175 \\
\hline
\end{tabular}


Finally, assigning weights $(0.2,0.4,0.4)$ to $(\alpha, \beta, \delta)$, that is, to the memberships obtained by each of the three methodologies (average, OWA and probability), it is possible to obtain the results shown in the last column of Table 7 ( $\mu$ weighted average), representing the water supply curve.

Table 7. Membership functions for willingness to accept

\begin{tabular}{|c|c|c|c|c|c|}
\hline WTP & Answers & $\boldsymbol{\mu}$ average & $\boldsymbol{\mu}$ OWA & $\boldsymbol{\mu}$ probability & $\boldsymbol{\mu}$ weighted average \\
\hline 0.00 & 0 & 0.00 & 0.00 & 0.00 & 0.00 \\
\hline 0.15 & 2 & 0.20 & 0.07 & 0.25 & 0.17 \\
\hline 0.30 & 3 & 0.30 & 0.14 & 0.50 & 0.31 \\
\hline 0.45 & 7 & 0.70 & 0.54 & 0.80 & 0.68 \\
\hline 0.60 & 7 & 0.70 & 0.54 & 0.80 & 0.68 \\
\hline 0.75 & 9 & 0.90 & 0.83 & 1.00 & 0.91 \\
\hline 0.90 & 10 & 1.00 & 1.00 & 1.00 & 1.00 \\
\hline 1.05 & 10 & 1.00 & 1.00 & 1.00 & 1.00 \\
\hline
\end{tabular}

\subsection{Equilibrium Price}

Figure 1 shows the equilibrium price of the water as a result of the intersection of the previously calculated demand and supply functions. This intersection allows obtaining an equilibrium price of $0.49 \$ \mathrm{~m}^{-3}$, with a membership function is 0.68 . The shape of these supply and demand curves depends on the attitude towards risk of the experts consulted [32]. It should also be noted that a greater membership function of the price obtained indicates weaker preference uncertainty.

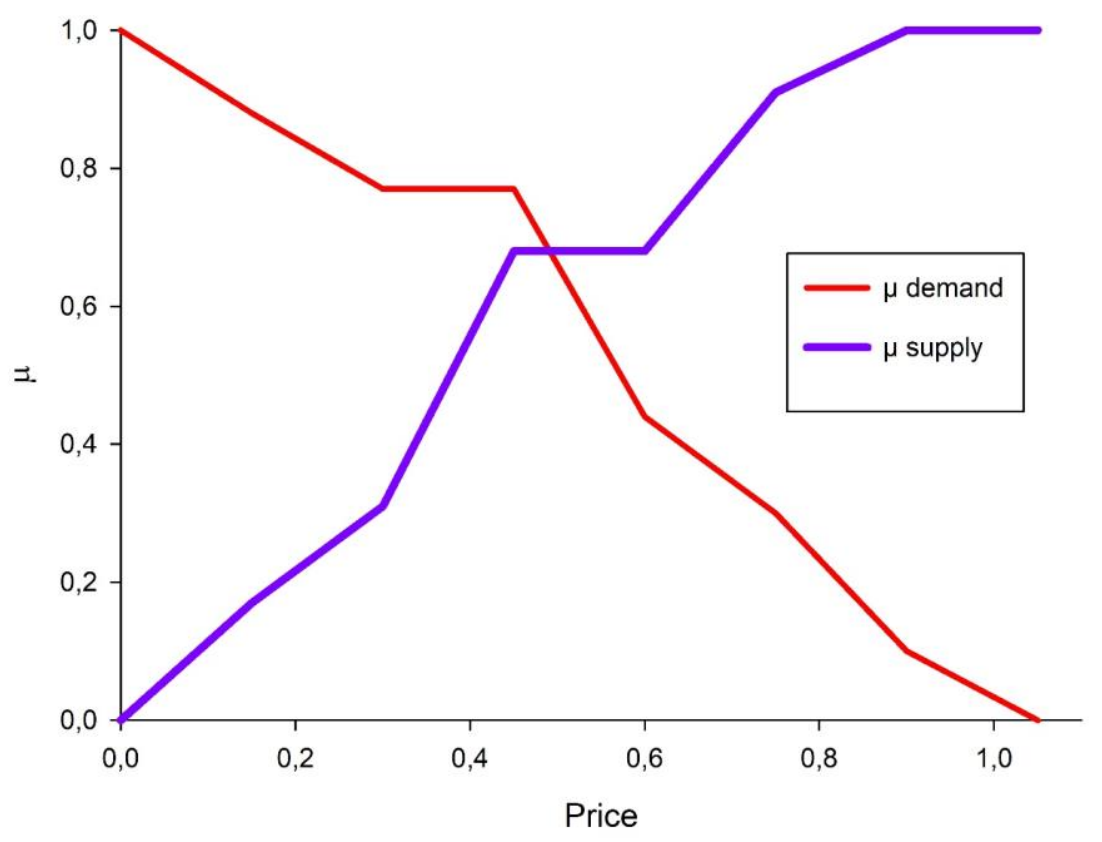

Figure 1. Equilibrium price

The obtained results are in line with those obtained by Rodríguez and García [22], who analyzed the water services payment in sugar cane in the Guayalejo Basin in the state of Tamaulipas, concluding that the price of water could be $\$ 0.39 \mathrm{~m}^{-3}$. On the other hand, Chávez and Mancilla 
[33] proposed a water rate applied to water users in the Pixquiac River, in Veracruz, Mexico, for which the opportunity cost method was used to assign value to the forest, obtaining a price of $\$$ $0.473 \mathrm{~m}^{-3}$ (see Figure 2). Other works show different willingness to pay, mainly due to the peculiarities of each area. For example, Barrantes [34] in the Savegre river in Costa Rica applied the cost per opportunity methodology and obtained a value of US $\$ 0.0010 \mathrm{~m}^{-3}$. In Mexico, Rodríguez and García [22] studied in the Guayalejo Basin in the south of the state of Tamaulipas, how they have been benefited from the water coming from the "Heaven Biosphere Reserve, obtaining $\$ 0.39 \mathrm{~m}^{-3}$. Finally, Chávez and Mancilla [33] proposed a water tariff applied to water users in the Pixquiac river, in Veracruz obtaining a value of $\$ 0.473 \mathrm{~m}^{-3}$.

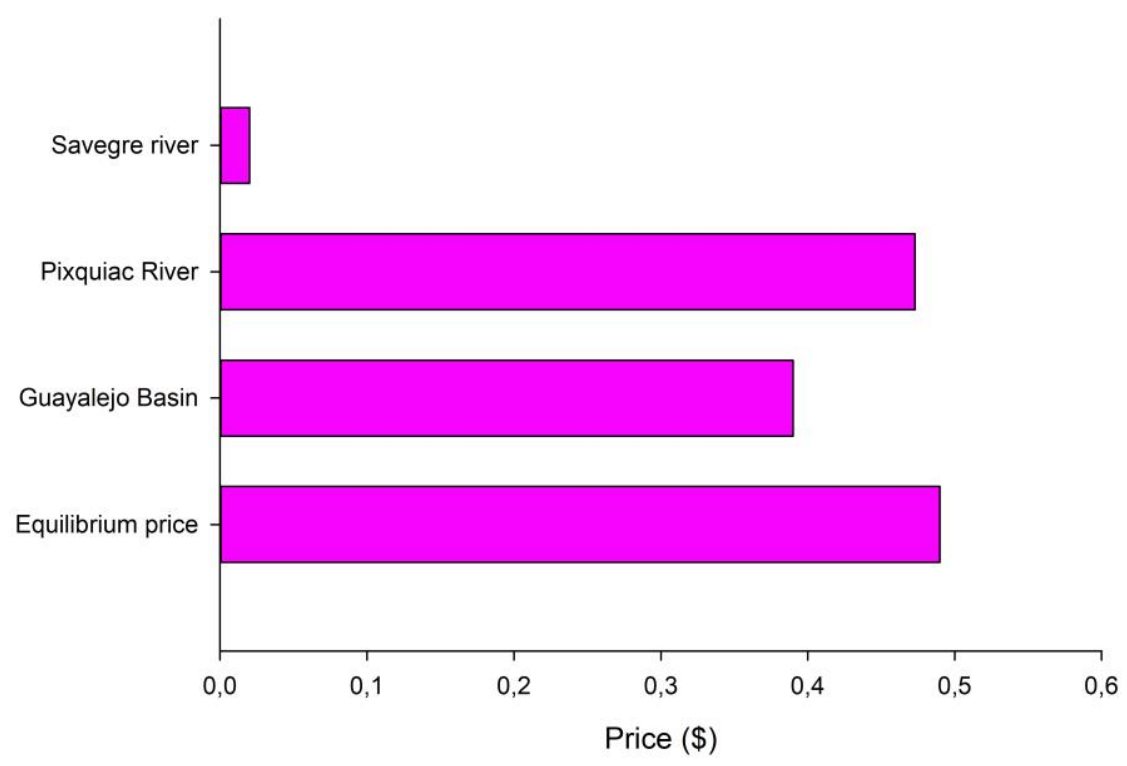

Figure 2. Comparison prices

It should be noted that the application of this methodology has allowed

- The determination of an equilibrium price by creating an artificial market

- The experts to grade their opinions regarding each price with the inclusion of linguistic labels.

- The introduction of OWAs allows graduation the final result according to different degrees of optimism or pessimism in the model

- The introduction of probabilities to each of the experts can improve the quality of the estimation because not all experts deserve the same trust, either because of their knowledge, or because of their interest in obtaining results that are positive for them.

We are aware that it is only an approximation, mainly because on numerous occasions, experts indicate their willingness to pay, something quite different is that if they had to pay, they would actually do it. Therefore, the introduction of fuzzy numbers and OWA extensions should improve the accuracy of the estimation. 


\section{Conclusions}

The main objective of this work has been to determine an equilibrium price for water in the Tancítaro area. For this purpose, the water users in the lower middle basin area (denser avocado fringe) have expressed the maximum price they would be willing to pay to ensure a continuous supply of water. In the same way, the inhabitants of the protected area (high basin) have expressed their opinion about the minimum price required by them to share their water resources.

The importance assigned to each expert has been considered in two ways, assigning a probability to each expert according the confidence degree in each one as well as just considering their provided values and aggregating them according several degrees of optimism or pessimism.

The fuzzy logic has been introduced in the way the experts express their opinions, using linguist labels. This methodology increases the flexibility of the model since it allows the experts not only to answer in a dichotomous way (yes or no), but also to graduate their opinions.

The intersection of the demand and supply functions allows obtaining the equilibrium price. We are aware that it is a preliminary work and final values may vary significantly compared to those offered in this work, but this paper aims to offer a new methodology applicable cases in which there is no market and it is necessary to create an artificial one to obtain the equilibrium price.

We want to point out that this is a preliminary work and we have used only probability OWAs, OWAs and means, but we are working in the application of some OWAS extension to the water demand and supply, such as induced OWAs. Anyway, the use of intuitionistic fuzzy numbers as well as hesitant fuzzy numbers will improve the quality of our research.

\section{REFERENCES}

[1] X. Labandeira, C. J. León \& M. X. Vázquez. Economía Ambiental Pearson Educación, S. A., Madrid, 2007 isbn 10:84-205-3651-2

[2] M. Lavado, L. Palma, \& M. Cárcamo. Transferencia Tecnológica, Servicios Ecosistémicos y CAPR: Mecanismos de vinculación integral para los diversos actores que conviven en una cuenca: Caso Innova Cuencas APR. Red ProAgua CYTED, Chile, 2013

[3] D. Herrador \& L. Dimas. "Aportes y limitaciones de la valoración económica en la implementación de esquemas de pago por servicios ambientales," 2002.

[4] R. H. Manson, 2004. Los servicios hidrológicos y la conservación de los bosques de México. Madera y Bosques, vol 10, n. 1, 2004, 3-20. Recuperado de http://www.redalyc.org/articulo.oa?id=61710101

[5] M. A. Almendarez-Hernández; L. A. Jaramillo-Mosqueira; G. Avilés Polanco; L. F. Beltrán-Morales; V. Hernández-Trejo \& A. Ortega-Rubio. Economic valuation of water in a natural protected area of an emerging economy: recommendations for el Vizcaino Biosphere reserve, Mexico Interciencia, vol. 38 n. 4, Venezuela, 2013, pp. 245-252. Available: https//www.redalyc.org/articulo.oa?id=33926985005

[6] UNESCO, "Valoración económica de los recursos hídricos". Programa Mundial de Evaluación de los $\begin{array}{lll}\text { Recursos } & \text { Hídricos } & \text { (WWAP), }\end{array}$ http://www.unesco.org/new/es/naturalsciences/environment/water/wwap/facts-and-figures/valuingwater/

[7] C. Ortíz-Paniagua, J.C. L. Navarro-Chávez and T. Cortez Ma. "Acercamiento a las metodologías de valoración económica de uso directo extractivo en el contexto de los ecosistemas y elementos para la gestión del desarrollo sustentable". Revista Nicolaita de Estudios Económicos, vol. IV, no. 1 enero junio, 2009. Pp. 57-84.

[8] SIAP. Servicio de Información Agroalimentaria y Pesquera Avance de Siembras y Cosechas.

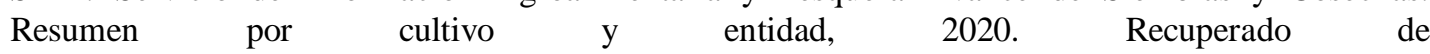
http://infosiap.siap.gob.mx:8080/agricola_siap_gobmx/ResumenDelegacion. 
[9] T. L. Villanueva \& J. A. Zepeda-Anaya (2018). "La Producción de Aguacate en el Estado de Michoacán y sus efectos en los índices de pobreza, el cambio del uso de suelo y la migración". Revista Mexicana Sobre Desarrollo Local, vol. 0, no 2. ISSN: 2395-863

[10] B. De la Tejera-Hernández; A. Santos; H. Santamaría; T. Gómez \& C. Olivares. "El oro verde en Michoacán: ¿un crecimiento sin fronteras? Acercamiento a la problemática y retos del sector aguacatero para el Estado y la sociedad" Economía y Sociedad, vol. XVII, no. 29, julio-diciembre, 2013, pp. 15-40. UMSNH, Morelia, Michoacán.

[11] Y. Raya-Montaño, P. Apáez-Barrios; S. Aguirre Paleo, M. Vargas Sandoval; R. Paz Da Silva \& M. Lara-Chávez. Identificación de hongos micorrizógenos arbusculares en huertos de aguacate de Uruapan, Michoacán. Revista Mexicana De Ciencias Agrícolas, vol. 23, 2019, 267-276. https://doi.org/https://doi.org/10.29312/remexca.v0i23.2026

[12] Gómez-Tagle (2018) Hydrological impact of the green gold (avocado culture) in central Mexico; rainfall partition and water use comparison with native forests. DOI: 10.13140/RG.2.2.18644.65921 Conference: Joint Conference on Forests and Water. Disponible en: https://www.researchgate.net/publication/329060308_Hydrological_impact_

of_green_gold_avocado_culture_in_central_Mexico_rainfall_partition_and_water_use_comparison_ with_native_forests

[12] J.J. A. Fuentes-Junco. Análisis morfométrico de cuencas: caso de estudio del parque nacional pico de Tancítaro. Instituto Nacional de Ecología. Dirección General de Investigación de Ordenamiento Ecológico y Conservación de Ecosistemas, 2004.

[13] INEGI. Censo de Población y Vivienda 2010, México: INEGI.

[14] L. Escobar-Jaramillo \& A. Gómez-Olaya. "El valor económico del agua para riego un estudio de valoración contingente", Ingeniería de Recursos Naturales y del Ambiente, vol 6, 2007, 16-32.

[15] D. Martínez \& H. Padgett. "Aguacate: "oro verde" de los templarios", Periodismo digital, 2013, Recuperado de https://www.sinembargo.mx/11-10-2013/780868

[16] J. Pérez Roas. "Valoración económica del agua". Centro Interamericano de Desarrollo e Investigación Ambiental y Territorial. CIDIAT. Universidad de los Andes, 2002, Mérida, Venezuela.

[17] C. Montes. Del desarrollo sostenible a los servicios de los ecosistemas. Ecosistemas, vol. 16, no. 3, 13. $2007 . \quad$ septiembre 2 Recuperado http://www.revistaecosistemas.net/index.php/ecosistemas/article/viewFile/87/84

[18] G. Barrantes-Moreno, "Valoración económica de la oferta de agua como un servicio ambiental estratégico", Ecological Studies, vol.185, 2006 M.Kappelle (Ed.). Ecology and Conservation of Neotropical Montane Oak Forests. Springer--Verlag Berlin Heidelberg.

[19] Nallathiga y Paravasthu "Economic value of conserving river water quality. Results from a contingent valuation survey in Yamuna River basin, India.". 2010.

[20] Soto G. "Estudio para estimar los beneficios ecológicos del proyecto integral para el saneamiento del Alto Atoyac, Puebla.", 2009.

[21] Sánchez. A et al "Cálculo de Disposición de Pago por Mejora en el Recurso Hídrico en la Cuenca del Río Apatlaco, Morelos, México. Usando el método de valoración contingente" 2010. Tesis. Universidad Pontifica católica de Chile.

[22] Rodríguez R. H., García, G, N., Cantero, M. D., Carreón, P. A., y Del C. Andrade L. E. "Pago por servicios hidrológicos ambientales en la cuenca del Río Guayalejo, Tamaulipas, México”. 2012. Papeles de Geografía, (55-56), 167-178.

[23] R.R. Yager "On Ordered Weighted Averaging Aggregation Operators in Multicriteria Decisionmaking", IEEE Transactions on Systems, Man and Cybernetics, vol. 18, no. 1, 1988, pp. 183-190.

[24] Liu, X.W. "A general model of parameterized OWA aggregation with given orness level", Int. J. Approx. Reason, Vol. 48, No. 2, 2008, pp. 598-627.

[25] Z. Gong, X. Xu, J. Forrest \& Y. Yang, "An optimization model of the acceptable consensus and its economic significance", Kybernetes, Vol. 45, No. 1, 2016, pp. 181-206.

[26] J.M. Merigó \& Casanovas, M. "Decision making with distance measures and induced aggregation operators", Computers \& Industrial Engineering, vol. 60, no. 1, 2011, pp. 66-76.

[27] J.M. Merigó, A. M. Gil-Lafuente \& R.R. Yager, "An overview of fuzzy research with bibliometric indicators", Applied Soft Computing, vol. 27, 2015a, pp. 420-433.

[28] J.M. Merigó, D. Palacios-Marqués \& B. Ribeiro-Navarrete, "Aggregation systems for sales forecasting", Journal of Business Research, Vol. 68, No. 11, 2015b, pp. 2299-2304.

[29] R.R. Yager, "Fuzzy logic in the formulation of decision functions from linguistic specifications", Kybernetes, vol. 25, no. 4, 1996, pp. $119-130$. 
[30] J.M. Brotons, M.E. \& Sansalvador. "Proposal for a Fuzzy Model to Assess Cost Overrun in Healthcare Due to Delays in Treatment". Mathematics, vol. 9, no. 408, 2021. https://doi.org/10.3390/math9040408.

[31] M.E. Sansalvador \& J.M. Brotons. "The Application of OWAs in Expertise Processes: The Development of a Model for the Quantification of Hidden Quality Costs". Economic Computation and Economic Cybernetics Studies and Research, vol 51, no. 3, 2017 73-90.

[32] G. Cornelis van Kooten \& E. Krcmar. "Fuzzy Logic and Non-market Valuation: A Comparison of Methods". IIFET 2000 Proceedings, 2000.

[33] M. Chávez Cortés \& K. E. Mancilla-Hernandez. "Charging Scheme for Hydrological Services Provided by the Upper Pixquiac River Watershed”. Tecnologia y ciencias del agua, vol 5, no 5:155170, September 2014

[34] C. A. Barrantes \& E. R. Flores. Estimating the willingness to pay for the conservation of andean rangelands. Ecol. apl. vol.12 no. 2 Lima ago./dic. 2013

\section{AUTHORS}

\section{José M. Brotons Martínez}

JM Brotons is Economist (1991, Alicante University) and $\mathrm{PhD}$ in Business Administration (2003). From 1999 he is a member of the Economic and Financial Studies Department of Miguel Hernández University in Elche (Spain). He has an 7 hindex (Web of Science), with 29 documents listed in Web of Science (7 in Q1 and 11 in Q2) and 118 citations (accessed on 18/11/2020). In the period 2010-2020, J.M. Brotons has contributed in 47 scientific publications ( 29 of them published in indexed journals in the Journal Citations Report), 29 national and international congress communications, 11 books; he has participated in 25 projects and 2 contracts; 6 end-of-

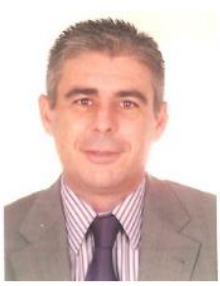
degree projects. He has obtained two recognised six-year research periods by CNAI and four five-years teaching periods. He is expert in financial valuation and economic analysis applied to the agriculture. In 2003 he defended the thesis "Financing of the Wastewater Treatment Company Sector. An Operational Approach". One of his interest research is the economic analysis of the agriculture production. Another interest research is the company financial valuation as a result of the use of new methodologies such as the innovations in fuzzy logic and the analysis of the quality system in the enterprises.

\section{Gerardo Ruíz Sevilla}

Ruíz-Sevilla is a Biologist graduated (1995) from the Michoacan University of San Nicolás de Hidalgo, later he obtained the degree of Master of Science (2002) from the Faculty of Biology of the same University and recently obtained the degree of Doctor (2021) for the Institute for Economic and Business Research with the research line of Water Ecosystem Services and Geographic Information Systems. He obtained a Diploma in Geographic Information Systems and Applications from the Institute for GeoInformation Science and Earth Observation (ITC) of the Netherlands and the Institute of

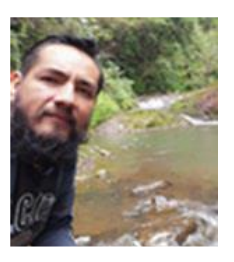
Geography of the UNAM (2003). He is currently a teacher at the National School of Higher Studies of the National Autonomous University of Mexico Morelia campus and has participated as an associate researcher in the project: Two-dimensional flow dynamics and sortive properties of the RAMSAR Pátzcuaro wetland, with (2012), Processing of the database and cartographic images of project No. 14: "Aquaculture Charter" of the program: Defense for the conservation of aquatic resources of the Fisheries Commission of the State of Michoacán. Morelia, Michoacán (2008), Associate Researcher in the project: Management of a wetland for the conservation of the lake coast in the south of Lake Pátzcuaro, (2010.), Associate Researcher in the project: The Zirahuén Lake Basin: Evaluation integral of its natural resources (2005), Associate Researcher in the project: CONACYT-SAGARPA 2003/245 Evaluation of the evapotranspiration of aquatic plants and its possible control in Lake Pátzcuaro through a chinampas module (2006), Associate Researcher in the project: Humedales de Pátzcuaro as a RAMSAR site. Secretariat of Urbanism and Environment of the Government of the State of Michoacán (2005). 


\section{Rubén Chávez Rivera}

R. Chavez is Chemical Engineering (1989, Michoacana University) and $\mathrm{PhD}$ in Administration (2010). From 2016 he is a member Basic Academic Core of the Masters and Doctors degree in Science of the Desarrollo Regional of Instituto Investigaciones Economico y Empresariales; professor and researcher of Facultad de Quimico Farmacobiologia and Licenciatura de Biotecnologia, Michoacan University in Morelia (Mexico). He has $3 \mathrm{~h}$-index (Web of Science), with 9 documents listed in Web of Science (1in Q2) and 36 citations (accessed on 18/11/2021). In the period 2016-2020,

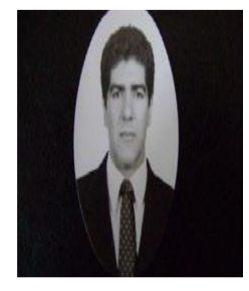
R. Chavez has contributed to 24 scientific publications ( 3 of them published in indexed journals in the Journal Citations Report), 26 national and international congress communications, 6 books; he has participated in 5 projects agro-industrial. He is an expert in economic analysis applied to regional agroindustrial development. In 2010 he defended the thesis "Strategic design for intellectual capital integration in organizations using diffuse logic". One of his interests in research is the energy economy and local development. Another interesting research is the company's financial valuation and economic optimization with innovations in fuzzy logic.

(C) 2021 By AIRCC Publishing Corporation. This article is published under the Creative Commons Attribution (CC BY) license. 